\title{
Coopetition Effect Determinants: Competitor's Size, Geographical Scope, Market and Technological Positions
}

\author{
Joanna Cygler ${ }^{1}$, Katarzyna Dębkowska²
}

\author{
${ }^{1}$ Warsaw School of Economics, Institute of Management, 162 Niepodległości, 02-554 Warsaw, Poland \\ cygler@sgh.waw.pl
}

\begin{abstract}
${ }^{2}$ Bialystok University of Technology, Faculty of Management, 2 Tarasiuka, 16-001 Kleosin, Poland
k.debkowska@pb.edu.pl
\end{abstract}

\begin{abstract}
Background and Goal: The article is aimed at conducting an empirical analysis of the value and significance of coopetitors' attributes thanks to which coopetition, which is a combination of cooperation and competition between competitors, generates a substantial corporate profit. Four major competitors' attributes have been analysed: its size, geographical scope, market and technological position. The research also includes the Porter's value chain.

Design/ Methodology/Approach: The survey has been conducted on a sample of 235 high- tech companies operating in Poland and involved in coopetition. The sample is representative. The data have been collected at interviews with company top executives or owners. The research applies the method of classification trees, which, thanks to diagrams, sequentially divides the examined data space into classes (spaces) of similar properties. The assessment of the effect of coopetition, including its variants, made by the examined company served as a dependent qualitative variable. Four coopetitor's attributes and their variants were assumed as explanatory variables (predictors) affecting the assessment of cooperation.

Results: The results of research indicated the necessity for an accurate competitor's profile selection. The significance of each of the four attributes may be different depending on the undertaken areas of cooperation with a competitor. The value of all the attributes of competitors is also diverse depending on the area of cooperation. A selected competitor's profile with regard to the four analysed attributes may become a stimulant to generate benefits in one area, while in another area it may become an inhibitor.

Conclusions: So far, the selection of a coopetition partner has been treated universally, without scrutinizing on some specific needs in relation to the area of cooperation. The selection of an appropriate coopetitor's profile will allow for the cost reduction in search of appropriate candidates for cooperation and in relations management.
\end{abstract}

Keywords: coopetition, effects, competitor's attributes, classification trees

\section{Introduction}

You have to kiss a lot of frogs to find a prince. It is one of the most popular quotations in business or scholarly economic literature (Rodan, 2002; Grisham, 2006). The primary inspiration of the message is referred to the Grimm brothers' fable entitled "The Frog Prince, or Iron Henry" (1812). However, there is some reference to fairy tales and myths from all over the world, e.g. Hungary, England or Korea. The quotation about frog kissing is most often used to illustrate the complexity of search for complementary resources strategically significant for the corporate growth due to the selection of partners for cooperation (Matthews, 1991). Aware of the time pressure and the difficulty to thoroughly assess partnership candidates, companies increasingly tend to reduce the number of candidates for cooperation in order to reduce the cost of identification and selection of appropriate organisations. It is becoming particularly important to pursue the search among competitors with which the companies are to create coopetitive 
relations, i.e. combining a simultaneous cooperation and competition among rivals (Bengtsson and Kock, 2000). The complexity of coopetition contributes to considerably higher costs of selection and consequences of mistakes with regard to the preferences for cooperation with the rival than in other inter-organisational relations.

The article is meant to indicate competitors' attributes in favour of coopetitive relations to bring substantial benefits to the selector. The analysis has been made in four major areas: competitor's size, market and technological positions, and geographical scope. These breakdowns are considered from the perspective of the Porter's value chain. It allows for the creation of the partners' profiles on the basis of which companies should make coopetition selections depending on the adopted value chain. Thanks to the selected desired profiles of candidates for coopetition, companies make a selection from a considerably less numerous groups of candidates, which decisively raises the probability of coopetition success. 235 high-tech companies operating in Poland have been analysed. The research makes use of one of multidimensional methods of statistical analysis, namely: the method of classification trees.

\section{The coopetition concept}

Coopetition belongs to the group of inter-organisational relations burdened with the highest costs (Lado et al., 1997). It results, for example, from the contradictory logic of activities: based on trust as well as conflict. In coopetition, trust is perceived in three dimensions: calculation (trust is based on calculation), understanding (trust is based on knowledge) and personal involvement (trust is based on identification), (Lane and Bachmann, 1998). They are subject to change in the process of coopetition relations between parties. The trust and common interests create the basis for efficient cooperation (Brito and Costa de Silva, 2009). Thanks to this, there is a growing tendency to contacts and mutual concessions (Harris and Dibben, 1999). On the other hand, the competition stream results from the fight for limited heterogeneous resources and from the race to win the same customers' favours (Brandenburger and Nalebuff, 1996).

Coopetitive behaviours are most often examined in the context of corporate relations. And coopetition is often regarded as an immanent element of corporate growth strategy (Dagnino, 2009). There are also analyses of simultaneous streams of cooperation and competition at the internal organisational level, in particular in transnational corporations (Luo, 2005; Luo et al. 2006; Slotegraaf and Tsai, 2002), individual people (Colley et al., 1985; Lu and Argyle, 1991; Simmons et al. 2001; Ross et al. 2003; Geraudel and Salvetat, 2014) and networks (Cygler 2010; Gnyawali and Madhavan, 2006, 2001; Bengtsson and Kock, 2000).
Coopetition is most frequently interpreted from the perspective of three theoretical trends: game theory, transaction cost theory and resource approach.

In game theory, coopetitive relations are treated as a positive-sum-game, i.e. creating the opportunity for all players to gain benefit. Coopetition is based in game theory on the classical analysis of the prisoner dilemma (Mayberry et al., 1992). In order to reduce opportunistic behaviours when solving the prisoner dilemma, a tit for tat strategy is employed (Axelrod, 1984) in pursuit of the principle of reciprocity of players, which encourages them to think strategically while executing individual movements. The coopetition activities are affected by the structure of payments, time horizon of activities and the number of players (Parkhe, 1993).

The inclination of the players to cooperate grows to accompany the growing significance of the shadow of the future as well as the stability of relations (Axelrod, 1984). Taking into account the number of players, cooperation relations between competitors lose stability and durability when the number of parties in the system increases. Opportunistic behaviours appear more often, which leads to the free riding strategy. In the game theory model of coopetition PARTS, Brandenburger and Nalebuff (1995, 1996) created the so-called Value Net. Multiple horizontal and vertical relations in the value net generate value added (a pie to be shared). It is considerably larger than in the case of connections within the value net than could be generated as a result of the individual activities of players.

In transaction cost theory, a selection is considered from among three main forms of organisational operation: market transactions, hierarchical structures and hybrid relations (Williamson, 1987). Companies choose coopetitive (hybrid) relations as a response to generating additional transaction costs as a result of market imperfectness (Hennart, 1988; Madhol, 2000) as well as hierarchical structures (Quintana-García and Benavides-Velasco, 2004; Park and Russo, 1996). Coopetition is a hybrid form most heavily burdened with transaction costs. It is caused primarily by the competitive character of competitive cooperation and the rise in uncertainty of the operation of parties as well as the complexity of relations (Chen et al., 2007). The trust among parties is also at a low level, which leads to the creation of so-called opportunistic cooperation (Hill, 1990). The retention of a stream of competitive relations raises the threat of the appearance of conflict situations, which besides opportunism, are a result of free riding activities as well as limited rationality (Selten 1998).

In the resource-based view, companies decide to cooperate with organisations possessing complementary and strategic resources. The cooperation with a company, which is also a competitor, possessing both supplementary and complementary resources allows for the generation of benefits arising from the synergy effect of the shared resources being the object of cooperation and the resources at 
the company's disposal (Chetty and Wilson, 2003; ClarkeHill et al., 2003). A limited access to deficit resources on the part of companies outside the relations is an advantage of coopetition (Das and Teng, 2000). Coopetitive relations are also established to jointly create resources: to develop new technologies, to create or jointly acquire information and knowledge and to gain coopetition competence (Heimeriks and Duysters, 2007).

Besides the three abovementioned major theoretical concepts, coopetition issues are more and more often examined from the angle of the achievements of the network theory (Gnyawali and Madhavan, 2001; Gnyawali et al., 2006; Lechner et al., 2006; Bentsson and Kock, 2000; Peng and Bourne 2009). There are also references to philosophy (Doz and Hamel, 1998; Luo, 2004), biology (Cygler, 2015) and law (Geradin, and McCahery, 2005; Levin and McDonald, 2006). Despite the diversity of scientific inspirations allowing for the analysis of the complexity of coopetition, the state of knowledge of this phenomenon should be considered to be going through a state of transition (Edmonson and McManus, 2007; Soppe et al., 2014).

\section{Selection of coopetition partners}

The literature on coopetition more and more often deals with the key success factors of these relations (Chin et al. 2008). One of them is the selection of coopetitors. Due to the relative novelty of coopetition issues and the early stage of development of research of these relations, the questions of attributes and criteria of selecting coopetitors are based primarily on the literature on alliances and networks (Cygler, 2010; Gulati, 1999, Clarke-Hill et al., 2003). The research on alliances indicates that $50 \%$ of them failed and, after 10 years of cooperation, the percentage increases to $80 \%$ (Aldrich and Auster, 1986). Coopetitive relations generate a higher level of transaction costs, which makes this percentage grow. Thus, the selection of an appropriate coopetitor is becoming an increasingly significant or even a key factor for the success of relations between parties (Cullen et al., 1995).

Due to the complex structure of coopetitive relations, the selection of a partner has a multicriteria character. The literature considers the issue of coopetition partners` selection in terms of relationship factors. It is most often indicated that coopetition is successful if the relations generate mutual benefits (positive-sum-game), mutual trust, commitment and communication management (Shah and Swaminathan, 2008; Akdoğan et al., 2015; Chin et al. 2008). And Geringer (1991) divided the criteria into two groups: task related (operation related: tangible and intangible assets with a special focus on know-how, financial resources, skills, access to distribution channels) and partner related (cooperation related: corporate culture, trust between partners, size and structure of the partner). This division combined relationship factors with strategic attributes of partner selection (Glaister and Buckley, 1997).

The resource-based view regards resource complementarity as one of the most important partner selection criteria. This allows for the collective creation of value (Ohmae, 1989; Hitt et al., 2000; Ritala and Hurmelinna-Laukkanen, 2009, Ritala et al. 2014). And the research conducted by Akdoğan et al. (2015) indicated the possession of supplementary resources as a very important factor making a competitor eligible for cooperation.

Despite the growing interest of researchers in coopetition partner selection, particular attention is focused on relationship factors. However, considerably less attention is paid to coopetitors' strategic attributes (Luo, 1998). More and more significance is ascribed to such attributes as the partner's size and its market position, geographical scope and technological position.

The factors connected with the coopetitor's size are becoming increasingly popular in the literature on management, although it presents divergent opinions. It indicates that cooperation with a comparable, or a smaller, partner allows for successful competition against a larger competitor (Gnyawali and Park, 2009) and points to easier control and relationship management (Soppe et al., 2014). In addition cooperation with a larger coopetitor allows for taking advantage of its experience (Alvarez and Barney, 2001, Glaister and Buckley, 1997; Stern, 2005; Gulati, 1999).

The criterion of market position is becoming more significant in the case of transnational coopetition relations. The global players pay attention to the market position of their local partners in order to take advantage of their knowledge of the market and the development possibilities arising i.e. economies of scale, access to distribution channels, favourable position in the business ecosystem, (Luo, 1997, 1998, and 2004). The market position gains significance in the case of coopetition in emerging markets, where the value of risk as well as investment attractiveness are placed on a higher level.

The coopetitor's geographical scope is connected with its foreign experience, cultural flexibility, application of modern management methods and market experience from different geographical areas, which results in a higher degree of communication efficiency and growing trust (Luo 1997). Thus, companies prefer cooperation partners with a broader geographical scope as the coopetition management costs decline.

The corporate technological position is related to the company's innovation capabilities (Brown and Eisenhardt, 1997), technological skills and commercialisation competence with regard to new technological solutions. This criterion is increasingly important in relation to the coopetition partner selection in technologically advanced sectors and shorter product life cycles force companies into involvement in considerable innovativeness which exceeds the financial and organisational capabilities of a single company (Bouncken and Kraus, 2013). 
The choice of four criteria, indicated above, stems from the fact that they are perceived as sensitive by both researchers and managers. This means that they are regarded as crucial in the initial partner selection for cooperation. Therefore, the paper is focused mainly on these criteria as the most fundamental, as well as the most differentiating, of the cooperation effects between rivals. However these attributes should not be regarded as sufficient for a partner proper selection, but rather as necessary ones.

The literature on coopetition discusses the problem of selection of partner's attributes without defining the object of cooperation between competitors. It is intuitively assumed that the volatility of significance and value of competitor's attributes depending on the coopetition area is a characteristic feature of the coopetitor selection complexity. This arises from the diversity of expected benefits and threats, and as a consequence, different coopetitor's attributes. This means that the relevance of coopetition candidate's attributes changes depending on the area of cooperation. Therefore, in the course of research two hypotheses are to be verified.

$H_{1}$ : The significance of coopetitor's attributes connected with its size, market and technological positions as well as geographical scope is diversified depending on the area of a company's cooperation with its competitor.

$H_{2}$ : The value of coopetitor's attributes connected with its size, market and technological positions as well as geographical scope is diversified depending on the area of a company's cooperation with its competitor.

The hypotheses verification is based the data derived from the surveyed sample. They were analysed through the classification trees method. In this way, a ranking of coopetitor's attributes in all the areas was created. This allowed for the verification of hypothesis $\mathrm{H}_{1}$. Furthermore, the application of this method allowed for the division of the examined companies into groups depending on the assessment of the cooperation with the competitor in all the areas. Belonging to the groups is based on coopetitor's attributes value indicated by the interviewed companies, which allowed for the verification of hypothesis $\mathrm{H}_{2}$.

\section{Methodology}

\subsection{Data description}

A multi-stage research was conducted at the end of 2012 and beginning of 2013. As a result, a group of 235 hightech companies involved in coopetition was selected. The selection of the research sample was affected by the characteristics of the sector and the universality of coopetitive relations created within it. All the data were collected directly in questionnaires. The respondents were company top executives or owners. The selection of the research sample was conducted at several stages. The high-tech sector was defined according to the OECD classification (2003). The surveyed companies were classified into seven basic industries: processing and manufacturing (16 companies), pharmaceutical sector (79), production of office equipment and computers (4), production of TV, radio and communication equipment (31), medical equipment production (54), spaceship production (16), and high-tech services (35). With regard to the size, the majority are small companies (130), followed by medium-sized (72) and the least numerous group includes large companies (33). Taking into account the organisational form, there are: 171 stand-alone companies, 49 - corporations, 13 - holdings and 2 - others. The majority of the analysed companies are domestic organisations (165) and the rest of them (70) operate on a transnational scale. The sample meets the requirements of representativeness of the population of companies operating in the high-tech sector in Poland.

\subsection{Measures/Variables}

The research applied the method of the so-called classification trees, which thanks to diagrams used, sequentially divides the examined data space into classes (spaces) of similar properties (Breiman et al.1993; Quinlan, 1993; Lewis 2000). The classification trees' methods have a wide application in management science, in particular in marketing: in the research connected with the acquisition of new buyers, churn analysis, fraud detection and questionnaire data analysis. The advantage of the classification trees' method results from the ability to present the most complex solutions (Breiman et al. 1993). The complexity of solutions is reflected in the structure of the classification tree itself. It consists of the root (the beginning of the recursive process), branches (connections between the root and following nodes), nodes (parent node - superior and child node - subordinate) and leaves (nodes in which there is no further splitting of data subspace).

The leaf node includes information about the classification of data in the subspace in a definite class. In every node a certain condition is checked (depending on the type of tree) with regard to a given observation and on its basis one of the branches leading to the next, situated below, node is chosen. The idea of developing a classification tree is to obtain a tool (model) allowing for the classification of future observations whose belonging to a definite class is not known.

The created tree is a predictive and descriptive model allowing for the description and presentation of patterns in a given set (Rokach, 2008). The process of tree building is based on the basis of recursive splitting (Kotsiantis, 2007), where in every next node another independent variable may be used. At every stage, all predictors (variables) are analysed and the one that allows for obtaining the most 
homogeneous subgroups is to make selection (Loh and Shih, 1997).

The split in a node is effected only on the basis learning trial vectors which reached the node and consists in the best (in a definite sense) split of this subtrial into two parts (in the case of binary trees), transferred to descendants (e.g. from parents to children, Esposito et al., 1997). There should be such a split so that the diversity of the obtained elements of the dataset reaching the descendants would be reduced to a minimum. The split pursuit requires an appropriate measure of class diversity in the node. From among a number of diversity measures used in the process of creation of classification trees, some typical measures used for binary trees may be indicated (Loh and Shih 1997):

- Gini index: $\mathrm{Q}=2 p(1-p)$

- entropy ratio: $\mathrm{Q}=-p \log _{2}(p)-(1-p) \log _{2}(1-p)$

where $p$ means probability of belonging to one of the classes.

Classification trees may be used to determine the belonging case to the quality class of a dependent variable on the basis of measuring of one or more explanatory variables (predictors), which may also be qualitative variables (Piccarreta, 2008). The assessment of the competitive cooperation made by the examined company is assumed as a qualitative variable.

The variants of this variable are: significant benefit, poor benefit, zero effect and loss. The explanatory variables (predictors) affecting the assessment of cooperation are four qualitative variables: partner's size (with variants: larger, smaller and comparable with the examined company), partner's technological position (with variants: stronger, weaker and comparable), partner's market position (with variants: stronger, weaker and comparable) and competitor's geographical scope (with variants: local/regional, domestic/national and international). The classification trees were constructed through the application of these variables in the value chain as the cooperation area: R\&D, input supply, production/services, sales/distribution, marketing, logistics, finance, IT and human resources. As a result, nine classification trees were obtained to breakdown the companies with regard to the cooperation effect in a given area depending on the competitor's attributes. The application of the classification trees method was preceded by the analysis cooperation assessment breakdowns in the area of coopetitive relations (Table 1).

From among 235 examined companies, the majority declared cooperation in at least two value chain areas. The analysis of breakdowns of cooperation effects indicates that there are differences in the assessment of competitive cooperation effects in particular areas. In order to confirm this thesis, verification was made of the hypothesis of the lack of differences in assessment of cooperation effects in the analysed areas through the Kruskal-Wallis test. The achieved level of the test amounted to 46.19932 as well as level $\mathrm{p}=0.0000$. These results indicate that the hypothesis of the lack of differences in assessment in coopetition areas is to be rejected. Thus, the examined companies are substantially different in their assessment of the effects in various areas of cooperation.

\section{Findings and discussion}

The method of classification trees was used in order to classify the examined companies in all the areas of cooperation taking into account the effects of competitive cooperation as well as their corporate attributes: competitor's size, technological and market positions, and geographical scope. Additionally, this method allowed for the determination of significance of particular predictors (competitor's attributes) with regard to the area of cooperation (Table 2).

Table 1: Assessment of competitive cooperation in different areas. Source: own calculations.

\begin{tabular}{|c|c|c|c|c|c|}
\hline \multirow{2}{*}{\begin{tabular}{|c|c|} 
Area of competitive cooperation \\
\cline { 2 - 6 }
\end{tabular}} & $\begin{array}{c}\text { Significant } \\
\text { benefit }\end{array}$ & Poor benefit & Zero effect & Loss & Total \\
\hline R\&D & 30 & 39 & 15 & 5 & 89 \\
\hline Input supply & 43 & 42 & 18 & 6 & 109 \\
\hline Production/Services & 66 & 46 & 18 & 0 & 130 \\
\hline Sales/ Distribution & 48 & 49 & 12 & 4 & 113 \\
\hline Marketing & 22 & 31 & 20 & 0 & 73 \\
\hline Logistics & 16 & 35 & 15 & 8 & 74 \\
\hline Finance & 9 & 27 & 16 & 8 & 60 \\
\hline Computer information systems & 26 & 31 & 21 & 0 & 78 \\
\hline Human Relations & 15 & 28 & 12 & 3 & 58 \\
\hline
\end{tabular}


Table 2: Significance of predictors in particular areas of competitive cooperation and prediction accuracy. (The significance of predictors is presented on the scale from 0 to 100). Source: own calculations.

\begin{tabular}{|c|c|c|c|c|c|}
\hline $\begin{array}{l}\text { Area of competitive } \\
\text { cooperation }\end{array}$ & $\begin{array}{l}\text { Preference for } \\
\text { partner's size }\end{array}$ & $\begin{array}{c}\text { Preference for } \\
\text { partner's technological } \\
\text { position }\end{array}$ & $\begin{array}{l}\text { Preference for } \\
\text { partner's market } \\
\text { position }\end{array}$ & $\begin{array}{l}\text { Competitor's } \\
\text { geographical } \\
\text { scope }\end{array}$ & $\begin{array}{c}\text { Prediction } \\
\text { accuracy }(\%)\end{array}$ \\
\hline R\&D & 99 & 73 & 58 & 100 & 60.7 \\
\hline Input supply & 100 & 66 & 48 & 92 & 54.1 \\
\hline Production/Services & 66 & 99 & 87 & 100 & 57.7 \\
\hline Sales/ Distribution & 63 & 81 & 94 & 100 & 57.5 \\
\hline Marketing & 86 & 100 & 77 & 99 & 61.6 \\
\hline Logistics & 77 & 100 & 67 & 56 & 60.8 \\
\hline Finance & 87 & 57 & 100 & 86 & 61.7 \\
\hline $\begin{array}{c}\text { Computer information } \\
\text { systems }\end{array}$ & 87 & 100 & 70 & 68 & 62.8 \\
\hline Human Relations & 75 & 81 & 100 & 60 & 65.5 \\
\hline
\end{tabular}

Depending on the area of competitive cooperation differences may be observed in the significance of preferred coopetitor's attributes. In the areas of R\&D and input supply, definitely the most significant preferences are those for both the competitor's size and geographical scope. In areas like production/services and marketing, the most significant preferences in coopetition are those for coopetitor's technological and market position. In sales/distribution, competitor's geographical scope and its market position are the most relevant attributes. In the areas of logistics and IT, there is one decisively relevant preference for partner's technological position. In addition, in the areas of finance and human resources the most important issue is the competitor's market position.

The analysis of the significance of preferences in particular areas cannot let it go unnoticed that the competitor's activity geographical scope is very important in 5 analysed areas of activity. The preference for the partner's technological position is relevant in four areas and the preference for the partner's market position in three areas. Partner's size is essential in two areas. The obtained results give rise to the positive assessment and verification of hypothesis $\mathrm{H}_{1}$.

The construction of classification trees included all 9 areas of cooperation (Appendix), for which the prediction accuracy was determined as the relation of accurately qualified companies to the number of all companies cooperating in a given area (Table 2). All trees indicated over 50\% classification accuracy and the best results were achieved in the classification trees built for the areas like human resources, finance and marketing. The results obtained in the course research were recorded in the form of fuzzy (ifthen) rules (Table 3 - Appendix). These rules are useful to determine the profile of a coopetitor, whose cooperation in particular areas is labelled with significant benefit, poor benefit, zero effect or loss. The accuracy rate is determined for all the rules calculated as the quotient of the number of companies of a given class observed in the final node and the number of all companies in the final node.

The analyses indicate that a great benefit from cooperation in the R\&D area is indicated by the companies which cooperate with partners of a comparable size, a stronger technological and market positions and the ones operating on the international scale. The benefit decreases when the selection refers to a larger but domestic competitor. Furthermore, coopetition will show a loss when the company decides to cooperate with a smaller competitor with a weaker market position and operating in the same country.

In the case of input supply as an area of cooperation, the company will derive a substantial benefit if it becomes affiliated with a competitor of a comparable size, operating on the international or domestic scale and representing a comparable or higher technological level. However, such a company should avoid cooperation with smaller competitors with a weaker or stronger technological position, a weaker market position and domestic scope (the coopetition results in a zero effect at its best).

Companies deciding to pursue competitive cooperation in the area of production/services should look for coopetitors with a stronger or comparable technological position and diversified geographical scope of activity (significant benefit from coopetition), while the cooperation with partners with a weaker technological position will not bring any benefit.

Competitive cooperation in the area of sales/distribution will generate a great benefit if companies select coopetitors which do have a higher than comparable market position and their geographical scope is confined to the domestic level. The competitors with a strong market and technological position should be avoided. However, co- 
operation with competitors with a strong market position in the area of marketing will bring a significant benefit. In this area, it is dangerous to join competitors with only a domestic scope representing at the most a comparable technological position and a weaker market position.

Logistic competitive cooperation requires the selection of a smaller or comparable partner with a comparable technological position and a stronger market position operating on the domestic market. A significant benefit may be expected then. On the other hand, when the selection of logistic cooperation results in larger or comparable companies with a stronger technological position and a weaker market position operating on the local or national market, a coopetitive fiasco may be expected.

Cooperation in the area of finance may generate considerable profits if companies choose a smaller or comparable coopetitor with comparable technological and market positions and operating on the domestic market. It is unfavourable to cooperate with a larger or comparable competitor with a weaker market position. Such relations may become disadvantageous.

As in the case of $R \& D$, competitive cooperation in the field of IT requires a coopetitor of a comparable technological positon and a stronger or comparable market position operating at least on the national market. Considerable benefit is to be expected from these relations. On the other hand, partners with a stronger or comparable technological position and a weaker market position operating on the local or national market may contribute to losses.

Companies which decide to pursue competitive cooperation in the area of human resources should choose organisations with at least comparable technological and market positions. The competitor's geographical scope plays a less significant role; thus any scope is acceptable. The relations likely to bring no benefit arise from the selection of partners with a weaker technological position.

The analyses prove that benefits derived from coopetitive relations depend on an appropriate selection of coopetitors. The values of competitors' attributes in certain areas of cooperation may stimulate the generation of benefits, but at the same time they may become inhibitors in others. This means that the selection of the area of competitive cooperation should result in a coopetitor of an appropriate profile of attributes, specific to this area.

The research also indicates that it is possible to search for common values of attributes of competitors to make the cooperative relations beneficial for companies in several areas. For example, it is worth cooperating with comparable competitors in the following areas: $R \& D$, input supply, logistics, IT and finance. Companies should look for competitors with a stronger technological position in the area of R\&D, HR, IT, production/services and input supply. However, a strong technological position poses a threat to the cooperation in the area of finance and sales/ distribution. A coopetitor's stronger market position helps to create relations benefit in the case of cooperation in the area of R\&D, logistics and IT. At the same time, a partner's strong market position may serve as a constraint in the area of sales/distribution, and cooperation with an international competitor may be advantageous for generated benefits in the case of coopetition in the areas of $R \& D$, IT, input supply and marketing. It is not profitable in the case of logistics and finance.

The research results explicitly prove the necessity for the differentiation of coopetitor's profile attributes (through the differentiation of their value) depending on the area of cooperation so that the relations between the parties could bring a significant benefit. This gives rise to a positive verification of hypothesis $\mathrm{H}_{2}$.

\section{Conclusions}

Undoubtedly, coopetition belongs to the most complex types of inter-organisational relations. This arises not only from the simultaneous occurrence of seemingly contradictory streams of relations, i.e. competition and cooperation, but also the requirements of attributes of particular parties. The research demonstrates that not all candidates for coopetition are appropriate, and the significance and value of these candidates' attributes depend on the area of cooperation.

The results of the research, besides having a cognitive character, have a substantial practical dimension. Companies may, on a preliminary basis, select competitors with whom the cooperation is more likely to generate a significant benefit from coopetition with regard to the four analysed attributes. At the same time, it is possible to make use of similar values of coopetitors' attributes, including several activities in the chain value. Such an approach reduces the search costs for coopetition candidates as well as the costs associated with coopetitive relations management. This means that the number of frogs to kiss may be ex ante limited.

However, the research presented also has its limitations. The sample surveyed is confined to high-tech companies operating in Poland. Additionally, the analyses refer only to four attributes. It therefore seems justified to extend the research in the geographical and sectoral dimensions as well as to extend the list of attributes to be considered when selecting coopetitors.

\section{Acknowledgements}

This paper was financially supported by the Ministry of Science and Higher Education in Poland [research grant no. NN 115 006040]. 


\section{References}

Akdoğan, A.A, Doğan, N.Ö., \& Cingöz, A. (2015). Coopetition as a Business Strategy: Determining the Effective Partner Selection Criteria Using Fuzzy AHP. International Review of Management and Business Research, 4(1), 137-151.

Aldrich, H., \& Auster, E.R. (1986). Even dwarfs started small: Liabilities of age and size and their strategic implications. Research in Organizational Behavior, 8, 165-198.

Alvarez, S.A. \& Barney, J.B. (2001). How entrepreneurial firms can benefit from alliances with large partners. Academy of Management Executive, 15(1), 139-148, http://dx.doi.org/10.5465/ AME.2001.4251563

Axelrod, R. (1984). The Evolution of Co-operation, New York: Basic Books Inc..

Bengtsson, M. \& Kock, S. (2000). Coopetition in Business Networks: to Cooperate and Compete Simultaneously. Industrial Marketing Management, 29(5), 411-426, http://dx.doi.org/10.1016/ S0019-8501(99)00067-X

Bouncken, R.B., \& Kraus, S. (2013). Innovation in knowledge-intensive industries: The double-edged sword of coopetition. Journal of Business Research, 66, 2060-2070, http://dx.doi.org/10.1016/j.jbusres.2013.02.032

Brandenburger, A.M. \& Nalebuff, B.J. (1995). The Right Game: Use Game Theory to Shape Strategy. Harvard Business Review, July-August, 5771.

Brandenburger, A.M. \& Nalebuff, B.J. (1996). Co-opetition. 1. A Revolutionary Mindset that Combines Competition and Cooperation. 2. The Game Theory Strategy That's Changing the Game of Business. New York: Doubleday.

Breiman L., Friedman J., Stone C.J., \& Olshen R.A. (1993). Classification and regression trees. New York: Chapman and Hall/CR.

Brito, C., \& Costa de Silva, S. (2009). When trust becomes the fourth "C" of cooperation. The Marketing Review, 9(4), 289-299, http://dx.doi. org/10.1362/146934709X479881

Brown, L.S., \& Eisenhardt, K.M. (1997). The art of continuous change: Linking complexity theory and time-paced evolution in relentlessly shifting organizations. Administrative Science Quarterly, 42(1), 1-34, http://dx.doi.org/10.2307/2393807
Chen, M.J., Su, K.H., \& Tsai, W. (2007). Competitive tension: The awareness-motivation-capability perspective, Academy of Management Journal, 50(1), 101-118, http://dx.doi.org/10.5465/ AMJ.2007.24162081

Chetty, S.K. \& Wilson, H.I.M. (2003). Collaborating with Competitors to Acquire Resources. International Business Review, 12, 61-81, http:// dx.doi.org/10.1016/S0969-5931(02)00088-4

Chin, K.-S., Chan, B.L., \& Lam, P.-K. (2008). Identifying and prioritizing critical success factors for coopetition strategy. Industrial Management \& Data Systems, 108(4), 437-454, http://dx.doi. org/10.1108/02635570810868326

Clarke-Hill, C., Li, H. \& Davis, B. (2003). The Paradox of Co-operation and Competition in Strategic Alliances: Towards a Multi-Paradigm Approach. Management Research News, 26(1), 1-20, http://dx.doi.org/10.1108/01409170310783376

Colley, A., Roberts, N. \& Chipps, A. (1985). Sexrole identity, personality and participation in team and individual sports by males and females. International Journal of Sports Psychology, 16, 103-112.

Cullen, J.B., Jonhson, J.L., \& Sakano, T. (1995). Japanese and local partner commitment to IJVs: psychological consequences of outcome and investment in IJV relationship. Journal of International Business Studies, 26(1), 91-115, http:// dx.doi.org/10.1057/palgrave.jibs.8490167

Cygler, J. (2010). Co-opetition in Network Relations between Businesses. Organization and Management, 1 (139), 59-71.

Cygler, J. (2015). Structural pathology in inter-organizational networks and the decision-making autonomy of its members. In: Sroka, W. and Hittmár, Š. (Eds.) Management of network organizations. Theoretical problems and dilemmas in practice. Heidelberg-New York: Springer Publishing, 181-195, http://dx.doi. org/10.1007/978-3-319-17347-4 13

Dagnino, G.B. (2009). Coopetition strategy. A new kind of interfirm dynamics for value creation. [in:] G.B. Dagnino and Rocco E., Coopetition Strategy. Theory, experiments and cases. London: Roulledge Studies in Global Competition.

Das, T.K. \& Teng, B.-S. (2000). A Resource-Based Theory of Strategic Alliances. Journal of Management, 26(1), 31-61, http://dx.doi.org/10.1177 


\section{$/ 014920630002600105$}

Doz, Y., \& Hamel, G. (1998). Alliance Advantage. The Art of Creating Value through Partnering, Boston: Harvard Business School Press.

Edmonson, A.C. \& McManus, S.E (2007). Methodological fit in management field research. Academy of Management Review, 32(4), 1155-1179, http://dx.doi.org/10.5465/AMR.2007.26586086

Esposito F., Malerba D., \& Semeraro G. A. (1997). Comparative analysis of methods for pruning decision trees. Machine Learning, 19(5), 476-491, http://dx.doi.org/10.1109/34.589207

Geradin, D. \& McCahery, J.A. (2005). Regulatory Co-opetition: Transcending the Regulatory Competition Debate, TILEC Discussion Paper, Tilburg University.

Geraudel, M. \& Salvetat, D. (2014). What are the antecedents of coopetition? European Business Review, 26(1), 23-42, http://dx.doi.org/10.1108/EBR-09-2012$\underline{0051}$

Geringer, J.M. (1991). Strategic determinants of partner selection criteria in international joint ventures. Journal of International Business Studies, 22(1), 41-62, http://dx.doi.org/10.1057/palgrave.jibs.8490291

Glaister, K.W., \& Buckley, P.J (1997). Task-related and Partner-related Selection Criteria in UK International Joint Ventures. British Journal of Management, 8, 199222, http://dx.doi.org/10.1111/1467-8551.00061

Gnyawali, D. R., \& Madhavan, R. (2001). Cooperative Networks and Competitive Dynamics: a Structural Embeddedness Respective. Academy of Management Review, 26(3), 431-445, http://dx.doi.org/10.5465/ AMR.2001.4845820

Gnyawali, D. He, J. \& Madhavan, R. (2006). Impact of Co-Opetition on Firm Competitive Behavior:An Empirical Examination. Journal of Management, 32(4), 179197, http://dx.doi.org/10.1177/0149206305284550

Gnyawali, D.R. \& Park, B.-J.R. (2009). Coopetition in technological innovation in small and medium-sized enterprises a multilevel conceptual model. Journal of Small Business Management, 47(3), 308-330, http:// dx.doi.org/10.1111/j.1540-627X.2009.00273.X

Grimm J. \& Grimm W. (1812). Kinder- und Hausmärchen, Göttingen.

Grisham, T. (2006). Metaphor, poetry, storytelling and cross-cultural leadership. Management Decision, 44(4), 486 - 503, http://dx.doi. org/10.1108/00251740610663027

Gulati, R. (1999). Network location and learning: The influence of network resources and firm capabilities on alliance formation. Strategic Management Journal, 20, 397-420. http://dx.doi.org/10.1002/(SICI)1097$0266(199905$

Harris, S. \& Dibben, M. (1999). Trust and Co-operation in Business Relationship Development: Ex- ploring the influence of National Values. Journal of Marketing Management, 15, 463-483, http://dx.doi. org/10.1362/026725799785045851

Heimeriks, K.H. \& Duysters, G. (2007). Alliance Capability as a Mediator Between Experience and Alliance Performance: An Empirical Investigation into the Alliance Capability Development Process. Journal of Management Studies, 44(1), 25-49, http://dx.doi. org/10.1111/j.1467-6486.2006.00639.x

Hennart, J.F. (1988). A transaction cost theory of equity joint ventures. Strategic Management Journal, 9, 361374, http://dx.doi.org/10.1002/smj.4250090406

Hill, C.W.L. (1990). Cooperation, Opportunism, and Invisible Hand: Implications for Transaction Cost Theory. Academy of Management Review, 15(3), 500-513, http://dx.doi.org/10.5465/AMR.1990.4309111

Hitt, M.A., Dacin, T.M., Levitas, E., Arregle, J., \& Borza, A. (2000). Partner selection in emerging and developed market contexts: resource-based and organizational learning perspectives, Academy of Management Journal, 43(3), 449-467, http://dx.doi.org/10.2307/1556404

Kotsiantis S.B. (2007). Supervised machine learning: a review of classification techniques. Informatica, 31(3), 249-268.

Lado, A.A., Boyd, N.G. \& Hanlon, S.C., (1997). Competition, Cooperation, And the Search for Economic Rents: A Syncretic Model. Academy of Management Review, 22(1), 110-141, http://dx.doi.org/10.5465/ AMR.1997.9707180261

Lane, C. \& Backhmann R. (eds.) (1998). Trust Within and Between Organizations. Oxford: Oxford University Press.

Lechner, Ch., Dowling, M. \& Welpe, I. (2006). Firm Networks and Firm Development: The Role of The Relational Mix. Journal of Business Venturing, 21, 514540, http://dx.doi.org/10.1016/j.jbusvent.2005.02.004

Levin, M. A. \& McDonald, R. E. (2006). R-A Theory as a post-Chicago Argument for Legal Coopetition. The Marketing Management Journal, 16(2), 1-12.

Lewis R.J. (2000). An Introduction to Classification and Regression Tree (CART) Analysis. Harbor-UCLA Medical Center in San Francisco, California (working paper)

Loh W.Y, \& Shih Y.S. (1997). Split selection methods for classification trees. Statistica Sinica, 7, 815-840.

Lu, L. \& Argyle, M. (1991). Happiness and Cooperation. Personality and Individual Differences, 12, 1019-1030, http://dx.doi.org/10.1016/0191-8869(91)90032-7

Luo, X, Slotegraaf, R. \& Pan, X. (2006). Cross-functional „coopetition”: The simultaneous role of cooperation and competitio9n within firms. Journal of Marketing, 70, 67-80, http://dx.doi.org/10.1509/jmkg.70.2.67

Luo, Y. (1997). Partner selection and venturing success: The Case of Joint Ventures with Firms in the People's Republic of China. Organization Science, 8(6), 648- 
662, http://dx.doi.org/10.1287/orsc.8.6.648

Luo, Y. (1998). Joint venture Success in China: How should we select a good partner? Journal of World Business, 33(2), 145-166, http://dx.doi.org/10.1016/S10909516(98)90003-7

Luo, Y. (2004). Coopetition in International Business, Copenhagen: Copenhagen Business School Press.

Luo, Y. (2005). Toward Coopetition within a Multinational Enterprise: a Perspective from Foreign Subsidiaries. Journal of World Business, 40, 71-90, http://dx.doi.org/10.1016/j.jwb.2004.10.006

Luo, Y. (2007). A coopetition perspective of global competition. Journal of World Business, 42, 129-144, http:// dx.doi.org/10.1016/j.jwb.2006.08.007

Madhola, A. (2000). Transaction (in)efficiency, value (in) efficiency and inter-firm collaboration, [in:] D. Faulkner\& de Rond, M. (eds.), Cooperative Strategy: Economic , Business, and Organizational Issues, Oxford: Oxford University Press.

Matthews, W. H. (1991). Kissing technological frogs: Managing technology as a strategic resource, European Management Journal, 9(2), 145-148, http://dx.doi. org/10.1016/0263-2373(91)90074-Z

Mayberry, J.P., Harsanyi, J.C., Scarf, M.E. \& Selten, R. (1992). Game - Theoretic Models of Co-operation and Conflict, San Francisco: Westview Press.

OECD 2003. OECD Science, technology and industry scoreboard 2003, OECD Publishing. [Online]. Retrieved 2013, December 30 from http://www. oecd-ilibrary.org/science-and-technology/oecd-science-technology-and-industry-scoreboard-2003 sti scoreboard-2003-en

Ohmae, K. (1989), The global logic of strategic alliances. Harvard Business Review, 67(2), 143-154.

Park, S. \& Russo, M.V. (1996). When competition eclipses cooperation: an event history analysis of joint venture failure. Management Science, 42(6), 875-890, http:// dx.doi.org/10.1287/mnsc.42.6.875

Parkhe, A. (1993). Strategic Alliances Structuring: A Game Theoretic and Transaction Cost Examination of Inerfirm Co-operation. Academy of Management Journal, 36(4), 794-829, http://dx.doi.org/10.2307/256759

Peng, T.-J. \& Bourne, M. (2009). The coexistence of competition and cooperation between networks: implications from two Taiwanese healthcare networks. British Journal of Management, 20(3), 377-400, http://dx.doi. org/10.1111/j.1467-8551.2008.00565.x

Piccarreta R. (2008), Classification trees for oridinal variables, Computational Statistics, 23, 407-427, http:// dx.doi.org/10.1007/s00180-007-0077-5

Podgorelec V., Kokol P., Stiglic B., \& Rozman I. (2006). Decision trees: an overview and their use in medicine. Journal of Medical Systems, 26(5), 445-463, http:// dx.doi.org/10.1023/A:1016409317640

Quinlan J.R.(1993). C4.5: Programs for machine learning. London: Morgan Kauffman.
Quintana-García C., \& Benavides-Velasco C.A., (2004). Cooperation, Competition, and Innovative Capability: a Panel Data of European Dedicated Biotechnology Firms. Technovation, 24, 927-938, http://dx.doi. org/10.1016/S0166-4972(03)00060-9

Ritala, P., Golman, A., \& Wegmann, A. (2014). Coopetition-based business models: The case of Amazon.com. Industrial Marketing Management. 43(2), 236-249, http://dx.doi.org/10.1016/j.indmarman.2013.11.005

Ritala, P., \& Hurmelinna-Laukkanen, P. (2009). What's in it for me? Creating and appropriating value in innovation-related coopetition. Technovation, 29, 819-829, http://dx.doi.org/10.1016/j.technovation.2009.07.002

Rodan, S. (2002). Innovation and heterogeneous knowledge in managerial contact networks. Journal of Knowledge Management, 6(2), 152 - 163, http://dx. doi.org/10.1108/13673270210424675

Rokach L., \& Maimon O. (2008). Data mining with decision trees. Singapore: World Scientific Publishing Co. Pte. Ltd.

Ross, S.R., Rausch, M.K. \& Canada, K.E. (2003). Competition and Cooperation in the five-factor model: individual differences in achievement orientation. The Journal of Psychology, 137(4), 131-139, http://dx.doi. org/10.1080/00223980309600617

Shah, R.H., \& Swaminathan, V. (2008). Factors influencing partner selection in strategic alliances: The moderating role of alliance context. Strategic Management Journal, 29(5), 471-494, http://dx.doi.org/10.1002/ $\underline{\text { smj. } 656}$

Selten, R. (1998). Features of Experimentally Observed Bounded Rationality. European Economic Review, 42, 413-436, $\quad$ http://dx.doi.org/10.1016/S00142921(97)00148-7

Simmons, C.H., Simrel King, C., Settle Tucker, S., \& Wehner, E.A. (2001). Success strategies: winning through cooperation or competition. The Journal of Social Psychology, 126(4), 437-444, http://dx.doi.org/10.1080/0 $\underline{0224545.1986 .9713610}$

Soppe, B., Lechner, Ch., \& Dowling, M. (2014). Vertical coopetition in entrepreneurial firms: theory and practice, Journal of Small Business and Enterprise Development, 21(4), 548-564, http://dx.do.org/10.1108/ JSBED-03-2014-0052

Stern, I. (2005). The Joint Venture Paradox: Patern-firm Characteristics, Social Cues, and Joint Venture Performance, University of Texas at Austin, (Ph.D. dissertation)

Tsai, W. (2002). Social Structure of "Coopetition" Within a Multiunit Organization: Coordination, Competition, and Intraorganizational Knowledge Sharing. Organization Science 13(2), 179-190, http://dx.doi. org/10.1287/orsc.13.2.179.536

Williamson, O.E. (1987). The Economic Institutions of Capitalism. New York: The Free Press. 
Joanna Cygler: M.A (Economics), Ph.D. (Management) and Habilitation (Strategic Management) from the Warsaw School of Economics (SGH). Associate Professor (Institute of Management, Faculty of Management and Finance) - SGH. Her research interests are related to international business cooperation. Authoress of numerous scientific publications on strategic alliances, business coopetition and network relations published in various countries. She worked for the Chancellery of the President of Poland (special advisor) and other central administrative institutions in Poland (Ministry of Economy, Ministry of Foreign Affairs). Prof. Cygler coordinated many research projects financed by Polish, European and American (Fulbright research scholarship, University of Minnesota) scientific organizations.
Katarzyna Dębkowska: M.A (Mathematics), Ph.D. (Economics), a faculty member of the Economic Informatics and Logistics Department (Faculty of Management) at the Technical University of Bialystok. Specializes in using quantitative research methods in business practice. Her research activities are focused mainly on the business models concept. Authoress of the analyzes in the following economic sectors: food, tourism, transport, e-commerce and e-services. Another area of both academic and practical interests deals with the use of foresight research. She is a member of the Polish Society for Production Management, IEEE and the statistic editor of a scientific journal "Economics and Management". 


\section{APPENDIX}

Table 3: The rules of the enterprises'classification in nine areas of competitive cooperation

\begin{tabular}{|c|c|c|c|c|c|c|c|c|c|c|c|c|c|c|c|c|c|c|c|c|c|c|c|c|}
\hline$\frac{\sqrt{\varrho}}{\frac{\alpha}{4}}$ & 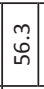 & 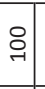 & \begin{tabular}{l|l}
$\stackrel{N}{\sim}$ \\
$\stackrel{1}{n}$
\end{tabular} & 吕 & in & ి. & $\begin{array}{l}\hat{\dot{b}} \\
\dot{0}\end{array}$ & ৪) & 웜 & $\stackrel{\bullet}{\tilde{\theta}}$ & 8 & 요 & in & $\begin{array}{l}\hat{\dot{b}} \\
\dot{0}\end{array}$ & ᄂ & 어 & 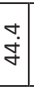 & $\hat{\emptyset}$ & $\begin{array}{lll}\tilde{N} & \\
& 1\end{array}$ & ז̊. & in & 8 & : & 욱 \\
\hline 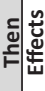 & 崖 & & & 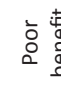 & & & & S. & & 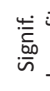 & & & $\begin{array}{ll}0 \\
0 \\
0 \\
0 \\
0 \\
0\end{array}$ & & 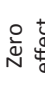 & & ") & 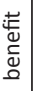 & & 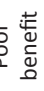 & & & 怘 & \\
\hline Ч & \begin{tabular}{|c|} 
\\
\\
\end{tabular} & & & \lrcorner & -1 & - & \begin{tabular}{l|l} 
& 0 \\
& \\
& \\
\end{tabular} & & - & $\begin{array}{l}\dot{j} \\
\underline{0} \\
\end{array}$ & 0 & \begin{tabular}{l|l} 
& \multicolumn{1}{|c}{} \\
& \\
\\
\end{tabular} & ○ & 하. & $-c$ & $\circ$ & $z$ & & $\begin{array}{l}\bar{\vdots} \\
\\
\end{array}$ & & 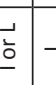 & - & & \\
\hline $\bar{\Sigma}$ & $\begin{array}{l}0 \\
\vdots \\
\vdots \\
\vdots\end{array}$ & $\begin{array}{l}u \\
\grave{b} \\
\vdots\end{array}$ & $\begin{array}{l}u \\
\vdots \\
\vdots \\
\vdots\end{array}$ & 3 & $\mid \begin{array}{l}0 \\
\vdots \\
\vdots \\
5\end{array}$ & 3 & 3 & $\begin{array}{l}u \\
\vdots \\
\vdots \\
\vdots\end{array}$ & 31 & $\begin{array}{l}u \\
\vdots \\
5 \\
5\end{array}$ & $\begin{array}{l}u \\
\vdots \\
\vdots \\
\vdots\end{array}$ & & & 3 & $3 \mid 3$ & 3 & $u$ & $u$ & $\begin{array}{l}3 \\
\vdots \\
0 \\
5 \\
5\end{array}$ & u & 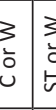 & $\begin{array}{l}3 \\
\vdots \\
\frac{1}{5} \\
\frac{1}{5}\end{array}$ & $\mid \begin{array}{l}3 \\
\vdots \\
\vdots \\
5 \\
5\end{array}$ & 5 \\
\hline 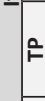 & 0 & $u$ & \begin{tabular}{|l|}
3 \\
0 \\
5 \\
5
\end{tabular} & 3 & $u$ & & $\begin{array}{l}0 \\
\vdots \\
5 \\
5\end{array}$ & \begin{tabular}{|l|}
3 \\
$\vdots$ \\
$\vdots$ \\
5 \\
5
\end{tabular} & 3 & $\begin{array}{l}u \\
\vdots \\
\vdots \\
5\end{array}$ & $\begin{array}{l}u \\
\vdots \\
5 \\
5\end{array}$ & 3 & $\begin{array}{l}u \\
\vdots \\
\vdots \\
5\end{array}$ & $\begin{array}{l}u \\
\vdots \\
\vdots \\
\vdots\end{array}$ & $\begin{array}{l}u \\
\vdots \\
\vdots \\
5\end{array}$ & & $u$ & $u$ & $\begin{array}{l}3 \\
3 \\
\vdots \\
5\end{array}$ & $\begin{array}{l}3 \\
\vdots \\
\vdots \\
5\end{array}$ & $\cup$ & & u & u \\
\hline in & $u$ & \begin{tabular}{l|} 
\\
$\grave{b}$ \\
$\sim$
\end{tabular} & $\begin{array}{l}u \\
\vdots \\
\infty\end{array}$ & & $u$ & & & $\backsim$ & & & $\begin{array}{l}\simeq \\
\vdots\end{array}$ & & $u$ & & $\begin{array}{l}n \\
\vdots \\
\infty\end{array}$ & & $u$ & $\backsim$ & & & u & & $\mid$ & $u$ \\
\hline $\begin{array}{l}\frac{8}{8} \\
\frac{0}{2}\end{array}$ & $\stackrel{2}{\sim}$ & $\sigma$ & 의 & $\stackrel{0}{\rightarrow}$ & 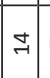 & $\wedge$ & $\approx$ & $\exists$ & ㄱ. & $\exists$ & $\stackrel{m}{\rightarrow}$ & $r$ & $\infty$ & 워 & $\underset{\sim}{\approx}$ & 6 & $\stackrel{\infty}{-1}$ & $\Rightarrow$ & $\approx$ & 6 & $\stackrel{n}{\sim} \stackrel{n}{n}$ & $m$ & $=7$ & $a_{0}$ \\
\hline$\frac{\pi}{\mathbb{2}}$ & & & !̣eu & $\begin{array}{l}\text { swa } \\
\text { uدofu }\end{array}$ & כ2s & $\begin{array}{l}\text { s } \\
\text { ond }\end{array}$ & Wo & & & & & ерәу & y ue & ewn & & & & & & & ueu! & & & \\
\hline$\frac{\grave{\partial}}{\frac{\pi}{4}}$ & 8 & $\stackrel{n}{\wedge}$ & ㄴ. & ه্ণ & $\mid \begin{array}{l}-1 \\
\text { o. } \\
\text { | }\end{array}$ & 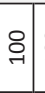 & & 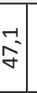 & $\begin{array}{l}\tilde{n} \\
\tilde{\Omega}\end{array}$ & 守 & $\begin{array}{l}\sim \\
\tilde{n}\end{array}$ & ְ. & 요 & in & $\stackrel{0}{0}$ & 억 & . & ஜ & $\stackrel{m}{m}$ & 요 & 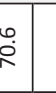 & & $\begin{array}{l}\infty \\
\stackrel{\infty}{\rho} \\
\dot{m}\end{array}$ & \\
\hline 氙 & & & 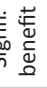 & & & $\begin{array}{l}0 \\
0 \\
0 \\
0 \\
0\end{array}$ & & & & 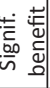 & & ¿ & & & वेt & 芯 & & 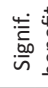 & & & | & & 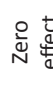 & \\
\hline$\tilde{\mho}$ & \begin{tabular}{|l|}
0 \\
$\vdots$ \\
\\
\end{tabular} & - & - & ذّ & \begin{tabular}{|l|} 
\\
\\
$\vdots$ \\
\\
\end{tabular} & \begin{tabular}{l|l} 
\\
$\vdots$ \\
\\
\end{tabular} & \begin{tabular}{l|l} 
& \\
$\vdots$ \\
$د$ \\
$د$
\end{tabular} & \begin{tabular}{|l|l} 
\\
\\
$\vdots$ \\
\\
\end{tabular} & إذ & 0 & ¿̀ & & & 0 & & 0 & 0 & - & - & - & $ـ$ & & & \\
\hline $\bar{\Sigma}$ & 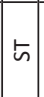 & \begin{tabular}{l|}
3 \\
$\vdots$ \\
$\dot{\omega}$
\end{tabular} & $u$ & $u$ & $u$ & $u$ & $u$ & 5 & 31 & $\begin{array}{l}u \\
\vdots \\
\vdots \\
\vdots\end{array}$ & $\begin{array}{l}u \\
\vdots \\
\vdots \\
\vdots\end{array}$ & 3 & 3 & $\begin{array}{l}u \\
\vdots \\
\vdots \\
\vdots\end{array}$ & 3 & $\begin{array}{c}u \\
\vdots \\
\llcorner \\
\llcorner\end{array}$ & & & 3 & 3 & $\begin{array}{l}u \\
\vdots \\
\vdots \\
\vdots\end{array}$ & & & \\
\hline ㄴ & & & & $\begin{array}{l} \\
\vdots \\
\vdots \\
5\end{array}$ & \begin{tabular}{|l|}
0 \\
$\vdots$ \\
$\vdots$ \\
\end{tabular} & & 3 & & & $u$ & & \begin{tabular}{l|}
3 \\
$\vdots$ \\
0
\end{tabular} & & ら & 5 & 3 & $\begin{array}{l} \\
\vdots \\
\vdots \\
5 \\
5\end{array}$ & $\begin{array}{l}u \\
\vdots \\
5 \\
\end{array}$ & $\begin{array}{l}0 \\
\vdots \\
5 \\
5\end{array}$ & $\begin{array}{l}u \\
\vdots \\
\bar{n} \\
\end{array}$ & $\begin{array}{l} \\
\vdots \\
\vdots \\
\vdots \\
5\end{array}$ & & 3 & \\
\hline in & $u$ & & & $\backsim$ & u & $\infty$ & $\begin{array}{l} \\
\vdots \\
\vdots \\
\sim\end{array}$ & \begin{tabular}{l|} 
\\
$\infty$ \\
$\vdots$ \\
$\vdots$ \\
\end{tabular} & & & & \begin{tabular}{l|} 
\\
$\vdots$ \\
$u$ \\
$u$
\end{tabular} & $n$ & & $\infty$ & & & & $\infty$ & $\begin{array}{l}n \\
\vdots \\
u \\
\end{array}$ & $\begin{array}{l}n \\
\vdots \\
u \\
\end{array}$ & & & \\
\hline $\begin{array}{l}\frac{0}{0} \\
\text { z }\end{array}$ & 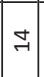 & 6 & $\nabla$ & ન & $\mid$ & $\infty$ & $\stackrel{m}{\rightarrow}$ & 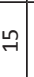 & $\exists$ & $\infty$ & in & $\exists$ & 6 & $\approx$ & 이: & $\stackrel{m}{q}$ & 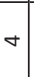 & 6 & $\infty$ & 요 & $\exists$ & & $N$ & \\
\hline 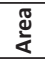 & & & & 8ิụฺว & эуגе & & & & & & & รวไุs & క! & & & & & & ח & גəS/ & /uoun? & ן. & podd & \\
\hline$\frac{\widehat{\partial}}{\frac{\alpha}{\alpha}}$ & $\begin{array}{l}\infty \\
\stackrel{\infty}{\wedge} \\
\end{array}$ & $\begin{array}{l}\mathscr{g} \\
\stackrel{f}{*}\end{array}$ & $\begin{array}{l}\infty \\
\dot{n} \\
i\end{array}$ & 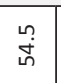 & \begin{tabular}{|l|}
$\stackrel{n}{n}$ \\
$\infty$ \\
\end{tabular} & in & 8 & ఫ్తి| & 8 & 员 & 이 & 8 & $\begin{array}{c}\infty \\
\dot{f} \\
\dot{f}\end{array}$ & $\begin{array}{l}\stackrel{\mathscr{q}}{\dot{\gamma}} \\
\end{array}$ & $\stackrel{-1}{\stackrel{1}{c}}$ & $\stackrel{m}{m}$ & $\begin{array}{l}\hat{n} \\
\tilde{n} \\
\end{array}$ & \begin{tabular}{|l|} 
\\
$\dot{f}$ \\
$\dot{f}$
\end{tabular} & $\triangleright$ & 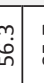 & $\begin{array}{cc}\hat{\infty} & \varnothing \\
\dot{\infty}\end{array}$ & 8 & 年 & 유 \\
\hline 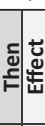 & 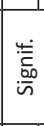 & & & 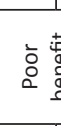 & & & 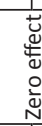 & & 으 & 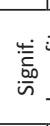 & & & 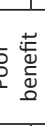 & & 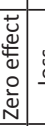 & $\begin{array}{l}\text { } \\
\text { Oิ }\end{array}$ & & 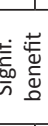 & & & 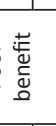 & & 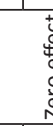 & 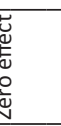 \\
\hline$\circlearrowleft$ & & - & & 0 & & & ○ & $\bar{~}$ & -1 & $\begin{array}{l} \\
\text { 흐 } \\
\end{array}$ & & - & \begin{tabular}{l|l} 
& ㅇ․ \\
흐 &
\end{tabular} & స. & - & - & $\begin{array}{l} \\
\\
\\
\end{array}$ & z & \begin{tabular}{ll} 
& \multicolumn{1}{|c}{} \\
&
\end{tabular} & \begin{tabular}{|l|} 
\\
\\
$\vdots$ \\
0
\end{tabular} & - & ــ & & - \\
\hline 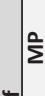 & $\left|\begin{array}{l}\vdots \\
\vdots \\
0 \\
v\end{array}\right|$ & \llcorner & $\begin{array}{l}\vdots \\
\vdots \\
\vdots \\
u\end{array}$ & $\begin{array}{l}5 \\
\vdots \\
\vdots \\
u\end{array}$ & $\left|\begin{array}{l}\vdots \\
\vdots \\
0\end{array}\right|$ & 3 & 3 & 3 & 31 & & & & & & & 3 & $\begin{array}{l}3 \\
\vdots \\
\vdots \\
u\end{array}$ & $\mid$\begin{tabular}{l|}
3 \\
$\vdots$ \\
0 \\
0
\end{tabular} & $\begin{array}{l}u \\
\vdots \\
\vdots \\
5\end{array}$ & 5 & $\begin{array}{ll}3 & \\
\vdots & 3 \\
u & 3\end{array}$ & 35 & 5 & 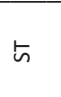 \\
\hline F & 5 & & $\begin{array}{l}5 \\
\vdots \\
\vdots \\
u\end{array}$ & & & $\begin{array}{l}5 \\
\vdots \\
0 \\
u\end{array}$ & 3 & 3 & 31 & & $u$ & & & $\begin{array}{l}3 \\
3 \\
\vdots \\
5 \\
5\end{array}$ & & $\begin{array}{l}3 \\
\vdots \\
5\end{array}$ & $\begin{array}{l} \\
3 \\
\vdots \\
\vdots \\
\end{array}$ & $\hbar$ & 离 & \begin{tabular}{|c|}
3 \\
$\vdots$ \\
$\vdots$ \\
\end{tabular} & 5 & 5 & $\sqrt{n}$ & $\begin{array}{l}3 \\
\vdots \\
0\end{array}$ \\
\hline v & $u$ & & $u$ & $\begin{array}{l}n \\
\vdots \\
\infty\end{array}$ & \begin{tabular}{|l|} 
\\
$\vdots$ \\
$\infty$ \\
\end{tabular} & & \begin{tabular}{l|}
$u$ \\
$\vdots$ \\
$\infty$
\end{tabular} & & $\sim$ & $u$ & $\backsim$ & \begin{tabular}{l|l}
$\infty$ \\
$\vdots$ \\
0
\end{tabular} & $\infty$ & $\backsim$ & 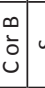 & $\backsim$ & & \begin{tabular}{|l|} 
\\
$\vdots$ \\
0 \\
$u$
\end{tabular} & & & & $\infty$ & & \\
\hline $\begin{array}{l}\frac{0}{0} \\
\frac{0}{2}\end{array}$ & $\infty$ & $\stackrel{\sim}{\sim}$ & a & $\stackrel{A}{A}$ & $\exists$ & $\wedge$ & $\stackrel{0}{-1}$ & $\underset{\nexists}{-1}$ & न & a & 6 & in & $\infty$ & $\exists$ & $\begin{array}{l}m \\
\Rightarrow\end{array}$ & 가 & $\exists$ & $\stackrel{9}{9}$ & $\stackrel{m}{\rightarrow}$ & a) & 67 & A & $\nabla$ & $\infty$ \\
\hline 敢 & & & & & $8 y$ & & & & & & & is & $\mathbf{s}$ & du & & & & & & & & & & \\
\hline
\end{tabular}



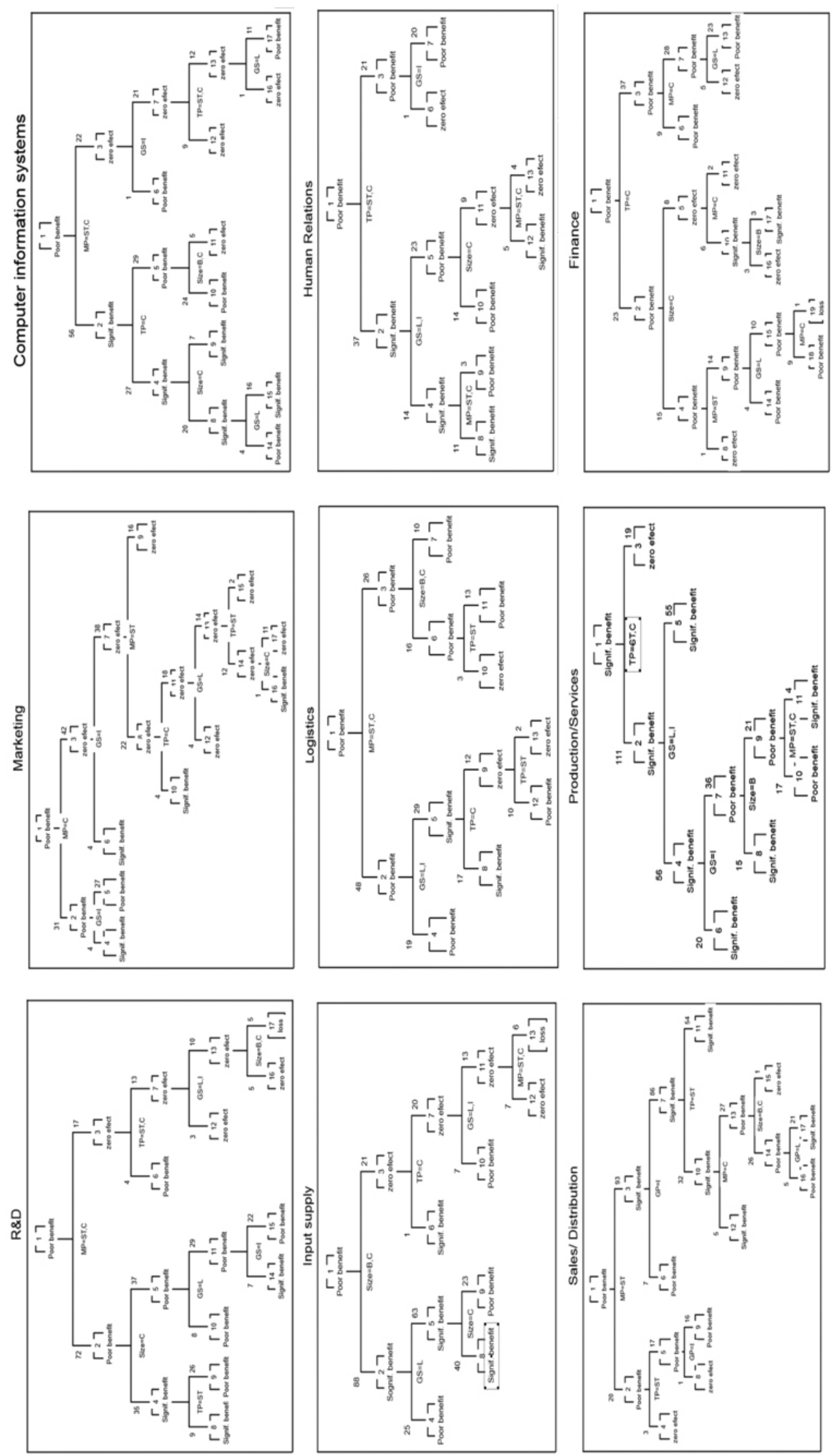

Figure 1: The rules of the enterprises' classification in nine areas of competitive cooperation 